Journal of Social and Development Sciences

Vol. 1, No. 2, pp. 48-59, Mar 2011

\title{
Sectoral Output Responses to Trade Openness, Oil Price and Policy Shocks in Nigeria: A CVAR Approach
}

\author{
Saibu M. O. \\ Department of Economics, Obafemi Awolowo University, \\ Ile-Ife, 234 220005, Southwest Nigeria \\ omosaibu@oauife.edu.ng
}

\begin{abstract}
This study investigated the relative effectiveness of trade and policy shocks on sectoral output growth in a small open Nigerian economy. It is a country-specific, time series study verifies whether there is difference in the effect of sectoral output response to policy shocks in Nigeria. A CVAR model was specified to assess the effects of policy shocks on real aggregate and sectoral output measures. The model included oil price shock and an interactive term of trade openness as measures of supply and external shocks to the economy. The empirical results showed that there was remarkably difference in sectoral output responses to policy distortion. The effects of monetary policy shocks were positive and significant on manufacturing, service and industrial sector while fiscal policy shock was only significant and positive on agricultural output growth. The result further showed that international oil price shock and trade openness had pronounced negative effects on both sectoral and aggregate outputs. In addition, oil and trade openness' negative effects overwhelmed the positive effects of fiscal and monetary policy shocks. The policy implication of the finding is that the effectiveness of domestic macroeconomic policy is constrained by the external shocks from both oil price and trade openness. Thus, confirming the open economic version of policy ineffectiveness proposition of the New classical macroeconomic in Nigeria
\end{abstract}

Keywords: Trade openness, oil price shocks, macroeconomic policy shocks, real output growth

\section{Introduction}

An increasing number of studies had begun to raise issue about the consequences of both oil price and trade policy on the effectiveness of domestic effort at mobilizing resource for growth. Ogun and Akinlo (2010) established that attempts to use monetary policy to stimulate economic growth through credit mobilization had been impaired by the external shock from the trade and financial reform in Nigeria. Similar Olomola and Adejumo (2006) also concluded that oil price shock contributed significantly to fluctuation in macroeconomic variables in Nigeria. However, little effort, in the previous attempts in Nigeria, was made at analyzing the role external shocks from both trade openness and oil price in this circumstance. Perhaps the fact that the Nigerian economy is trade and oil dependent makes such analysis exigent. Nigerian industries depend on capital and raw material imports while the government finances depend heavily on oil exports. The predominance of agricultural employment makes the majority of the people to depend on agricultural export earnings and imported manufactured goods to supplement the little that is produced locally. Hence, overall external trade policy of government has crucial role in facilitating the smooth running of the economy.

In developed countries research has so far focused on the real effects of aggregate demand policy, to see if they enhance our appreciation of the aggregate transmission mechanism relationships Such studies include Ganley and Salmon (1996), Dale and Haldane (1995), and Gertler and Grilchrist (1994). This study attempts to use similar approach and compare the response of real aggregate and sectoral outputs to an unexpected policy change in a small open developing Nigerian economy. In addition, the role of interactive effects of economic openness and real oil price shock were also investigated. Separate VARs was estimated for each of the identified output measures and compare the effect of a policy shock on each sectoral output measure and use the Impulse Response Function (IRF) and Variance Decomposition (VD) estimates generated from the VARs as the basis. The focus is principally on the size and timing of the impact of oil price and the other macroeconomic variables on real output fluctuations. These key characteristics of the transmission mechanism provide valuable information the effectiveness of policy in stimulating real; growth. The size of response in each sector indicates how the impact of unanticipated changes aggregate demand and supply shock are distributed 
across the economy; while the timing of these responses suggests how long the 'real' effects of the policy innovation may persist. In addition the impulse responses were explained in term of the degree of economic openness. The interplay of the policy shock response with the degree of economic openness provides some evidence on the relative importance economic liberalization on the transmission mechanism of macroeconomic policy in Nigeria. Apart from this introduction, the paper is divided into four other sections. Section two provides a brief and concise review of some related studies while section three discusses the methodological approach adopted in analysis the dynamic response of real output to policy shocks. Section four is devoted to empirical analysis and section five concluded with policy implications.

\section{Review of Related Studies}

Sim (1980) seminal paper pioneered this approach by using VAR methodology to examine macro-policyoutput interactions. He employed impulse response functions to analyze the effects of each endogenous variable's responses to unanticipated policy shocks. He found that unanticipated monetary policy shocks had significant effects on real output. In order to check the robustness of Sim (1980) results, Stock and Watson (1989) re-examined the output effects of unanticipated policy using both three (output, prices, and money) and four (output, prices, money, and interest rates) variable using Sims' VAR systems. The findings of this study revealed that that unanticipated changes in money growth had statistically significant but marginal predictive value for industrial production. Friedman and Kuttner (1992) also found that evidence based on the most recent U.S. experience did not indicate a close or reliable relationship between money and nonfinancial economic activity. Similarly Gauger and Enders (1989) classified the real output into aggregate and sub sectoral (disaggregate level) output in the US economy to investigate the possible different effects monetary policy could have on the different sectors of the US economy. They found no strong evidence in support of differential real effects of monetary policy; indeed their conclusion was that the impact of monetary policy was statistically insignificant in most of the sectors.

On the implication of degree of economic openness on the effectiveness of monetary policy, Romer (1993) investigated the relationship between openness and inflation. He argued that the absence of pre-commitment to monetary policy led to inefficiently high inflation. He claimed that the less open economy would have a greater incentive to expand and so had a higher equilibrium inflation rate. This relation could be explained as thus: unanticipated monetary expansion caused real exchange rate depreciation and since more open economies were more vulnerable to the harms of real depreciation, then the benefits of unanticipated expansion tended to be negatively correlated with the degree of openness. Therefore, if the money authority considered openness as an important state variable for the monetary policy, monetary authorities in more open economies would on average expanded money supply less and would have lower average rates of inflation. Dennis (2001) argued also that the well-known result of depreciation of domestic exchange rate was increasing inflation. Dennis concluded that whether the money authority intervenes or not opening the economy to external influence led to absence of pre-commitment in monetary policy. So output expansion was less but inflation. Bryant, et al (1988), in their empirical study by more than 10 macro-econometric models, predicted that monetary expansion raised output and the price level while a contraction had the opposite effects. Karras (1999a) and Guncavdi and Kucukcifci (2001) confirmed the same theory. Burement and Dogan (2001) assessed whether the increasing degree of openness affected the effectiveness of the monetary policy for an open economy. Quarterly data from 1987:1 up to 2001:1 period for Turkey was used to estimate the relationship between openness and the effects of monetary policy on output and prices. The measure of openness was interacted with the monetary policy measures to examine the implication of openness on the effects of monetary policy. The findings supported the theoretical expectation that 'monetary expansion reduces output growth substantially in a small open economy. This result buttressed the Romer's (1993) findings, which demonstrated a negative relationship between monetary policy and the degree of openness.

Blanchard and Gali (2007) investigated the effects of oil price shocks on a set of macroeconomic variables from a group of industrialized economies in the aftermath of the oil price shocks of the 1970s and of the last decade, focusing on the differences across episodes. The paper examined four different hypotheses for the mild effects on inflation and economic activity of the recent increase in the price of oil: (a) good luck (i.e. lack of concurrent adverse shocks), (b) smaller share of oil in production, (c) more flexible labor markets, and (d) 
improvements in monetary policy. The paper concluded that all the four scenarios have played an important role in influencing the macroeconomic performance. While an array of studies has been conducted on other countries less attempted was made with respect to Nigeria. In view of the reliance of Nigerian government on macroeconomic policy as instrument to stimulate output and stabilize prices, it is crucial to examine the efficacy of such policy thrust amidst the simultaneous liberalization of the Nigerian economy.

\section{Empirical Methodology}

A five variable cointegrating VAR is specified, interpreting each system as an unrestricted vector error correction model. To identify the policy shocks the Choleski decomposition was used in line with Bernanke and Blinder (1992). As well known, this identification procedure is somewhat ad hoc and relies on recursive relationship existing between the data. Following Karras (1999a, b); and Apergis and Miller (1998), we included oil price shocks as a measure of supply shocks. No reason exists to assume that the aggregate supplies in the Nigerian economy over the sample period remained stable where competitive markets do not exist. Our preferred ordering of the VARS is

\begin{tabular}{|c|c|}
\hline her & 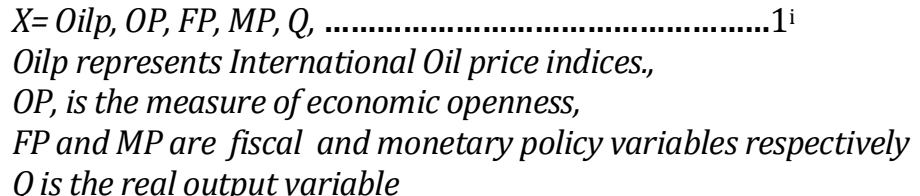 \\
\hline
\end{tabular}

This ordering stems from both economic theory and orthogonality of structural innovations. The placement of external shock variables first is based on the fact that the external development is important to domestic economic conditions and indeed the small but open assumption of the Nigerian economy. Therefore, all external variables are assumed to influence country specific variables. None of the country specific variable is assumed to influence the external variables. Given the importance of oil in the Nigerian economy, oil price was included as a measure of supply shock in line with Karras (1999a, 1999b) and selected as the first variable, contemporaneously affecting all other variables. The second variable in the ordering is the openness (OP), which is also assumed to have contemporaneous effects on all other variables except the first. The placement of the policy variables of interest FP, MP next, is consistent with the familiar textbook treatment of aggregate supply and aggregate demand in which current period shocks to the policy variables can affect real output contemporaneously.

Because our aim is to compare results across a series of VARS, we imposed common lags length of three on each of them. The choice of this lag length has the advantage of whitening the errors for the each of the individual VARS and is consistent with the notion that the maximum effect of the macroeconomic policy on real output does not exceed 36 months to manifest itself in Nigeria ${ }^{1}$. An alternative approach is to calculate the optimal lag length for each VAR separately, and carry out analysis with differing lag lengths. But in this case, we may be unsure whether differences in the profile of real aggregate and sectoral output responses to policy shocks simply reflect differences in the lag lengths of each VAR

\section{Description and Sources}

Annual time series for the period between 1960 and 2003 are used to estimate the models specified. This period was specifically chosen to trace the effects policy before the advent of recent macroeconomic reforms that took place in Nigeria in 2004. The sources of data on each variable are stated explicitly below. All variables are collected from various editions of Statistical Bulletin published by Central bank of Nigeria. Output is proxied by GDP; two measures of fiscal and monetary policies are used in the analysis. Government expenditure and non oil revenue represents the fiscal policy while broad money supply and interest rate represents the monetary policy measures. Openness is measure as the sum of non oil export and import as

\footnotetext{
${ }^{1}$ Olaloye AND Ikhide (1995) found out that the response lag in monetary and fiscal policy is between 24 and 36 months (two and three years).
} 
ratio of GDP and oil price oil price is proxied by the naira equivalent of international oil price. That is the US Dollar Oil Price is converted using the appropriate exchange rate for each year.

\section{Empirical results}

The sources of changes in the growth rates of real outputs were examined through the computation of impulse response functions (IRFs) and variance decomposition (VDC), which in turn were based on the moving-average representation of the CVAR model. The variable were found to be integrated of order one and there was at least one cointegration relationships among the variables thus permitting the estimation of the model with the multivariate cointegration mechanism The IRF indicated the direction and size of the effects of a one standard deviation shock to one variable on other variable in the system over time. The VDCs showed the percentage of the forecast error variance for each variable that might be attributed to its own innovations and to fluctuations in other variables in the system. Both the IRF and the VDC were used to determine the effectiveness and transmission mechanism of policy shocks in the system in line with standard practices.

\section{Impulse Response Function Analysis}

As earlier stated, the variables were ordered as: Real oil price, (OILP), Openness (OPEN), fiscal policy (FP1 and FP2 for expenditure and non-oil revenue respectively), monetary policy (MP1 and MP2 for money supply and interest rate respectively), and the real output of interest as usually were aggregate output (Qgdp), industrial $\left(Q^{\text {ind }}\right)$, manufacturing $\left(Q^{\text {man }}\right)$, service $\left(Q^{\text {serv }}\right)$, and agricultural output ( $\left.Q^{\text {agric }}\right)$. The placement of the oil price and openness variables first was based on the assumption that the Nigerian economy was characterized as a small open economy during the period of investigation so that current-period shocks to both openness and real oil price were allowed to influence domestic variables, but the domestic economy could not contemporaneously affect external variables. Odusola and Akinlo (2003) had argued that the interpretation of the impulse response function from VECM model should take into consideration the use of first differencing of the variables as well as the vector error correction estimates. Thus, a one-time shock to any of the first difference variable used in this study was a permanent shock to the level of that variable. This allows the determination of the impacts monetary and fiscal policy shocks as well as openness and oil price shocks on real outputs. Figure 1 depicted the impulse response functions of the variables mentioned above. The maximum value of IRFs represents the peak effect while the time horizon for the graph to decay gave the timing of the policy effect on real output.

A cursory inspection of the impulse responses reported in Figure 1 showed that the real output effects of the policy; openness and real oil price innovations fluctuated, though with low amplitude but converged after some time to constant value as expected for any cointegrated series. Using the signs to draw economic meaning from the estimates and starting from the two non-policy variables, The signs indicated pervasive impacts of both oil price and openness shocks on real output across the sectors and time horizons. With respect to aggregate output, oil price shock had positive effects across the time horizons. Its effects ranged between 0.8 and 0.2 across the periods. Intuitively, this result suggests that a permanent shock to the oil price could result in a temporary positive impact on real economic growth, which declined progressively overtime. Openness shock impacts fluctuated across the period. It was negative in the in four out of the ten lag periods: $2^{\text {nd }}(-0.02), 3^{\text {rd }}(-.0 .2), 5^{\text {th }}(-0.008)$ and the $10^{\text {th }}(-0.02)$ lags. A further observation shows that the negative effects overwhelmed the positive impacts across the horizon, implying that openness had contractionary effects on the growth of real aggregate output.

In terms of sectoral output responses, the industrial output responses remarkably differed from the other sectors' responses to openness shocks. Industrial output responded positively at increasing rate to shocks from openness while the impacts of oil price had no explicitly discernible pattern. The observation that output responded more positively to openness shocks is worthy of note. These industrial output responses seemed contradictory to general opinion that the trade liberalization has affected the industrial production especially manufacturing sector adversely. The results reported here do not support this position. Perhaps, the trade liberalization had put the manufacturers on their toes. They had been forced to be more innovative, creative and proactively enterprising. The competition is now high and intense. Indeed, the effect of this 
competition is really being felt in term of quality and productivity. This improved quality is more noticeable in the detergent, beverages, cosmetics and confectioneries industries where it is becoming more difficult to differentiate between the local and imported products.

The effects of fiscal expansion on sectoral output growths were admixture of both positive and negative impacts but there was evidence of overwhelming positive effects over the negative effects in both fiscal expansion (expenditure growth i.e. FP1) and tightening (non oil revenue i.e., FP2). In sharp contrast to evidence from the fiscal policy propagation, monetary policy impacts on both aggregate and sectoral output were consistent with economic theory. The monetary expansion through money supply growth had positive impacts while the monetary policy tightening had negative impacts on real outputs. Interestingly, none of the money supply shocks had negative signs while interest rate policy shocks (MP2) also had negative signs in almost on all point estimates. One important observation that merit further elaboration was the net real effects of both fiscal and monetary policy expansion and contraction. A closer and deeper look at the point estimates across the output measures and time horizon revealed the relative adverse effects of the macroeconomic policy variables used on the analysis. Comparing the size of effects of fiscal expansion (FP1) to monetary policy expansion (MP1) showed that in the case of aggregate output, the negative effects of fiscal expansion overwhelmed positive effects from the monetary expansion across time horizons.

Figure 1: The Plots of Impulse Response Functions of Real Output Growth to Policy and Openness shocks

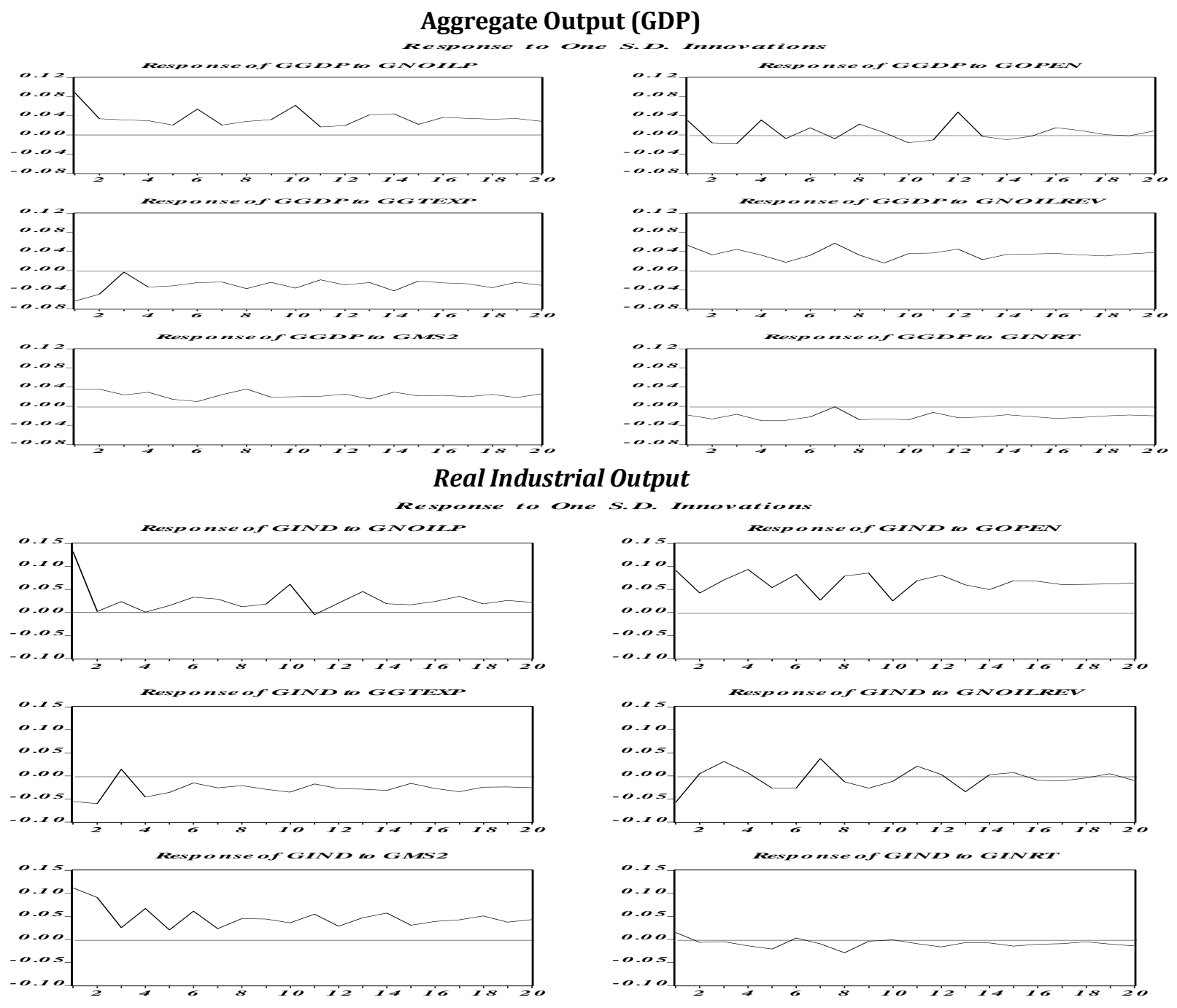


Real Manufacturing Output

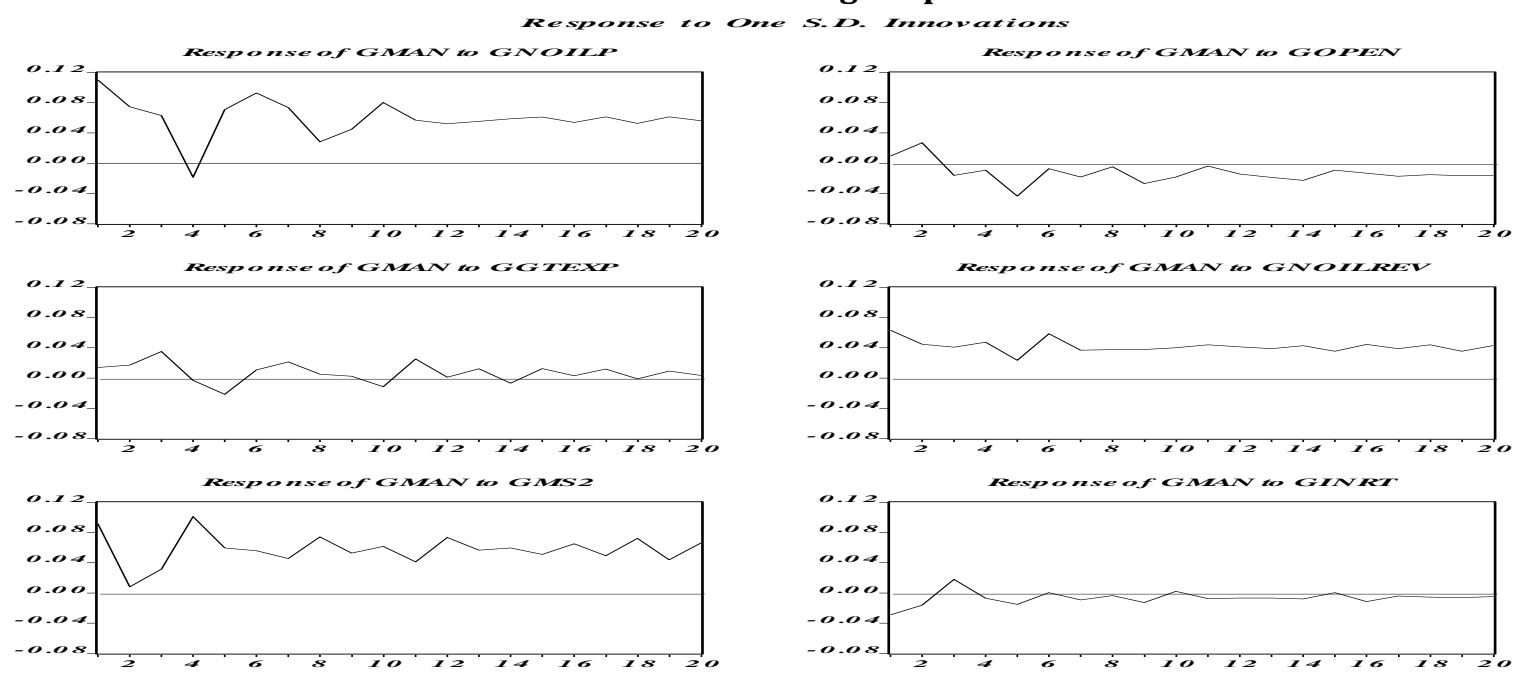

\section{Real Service Output}
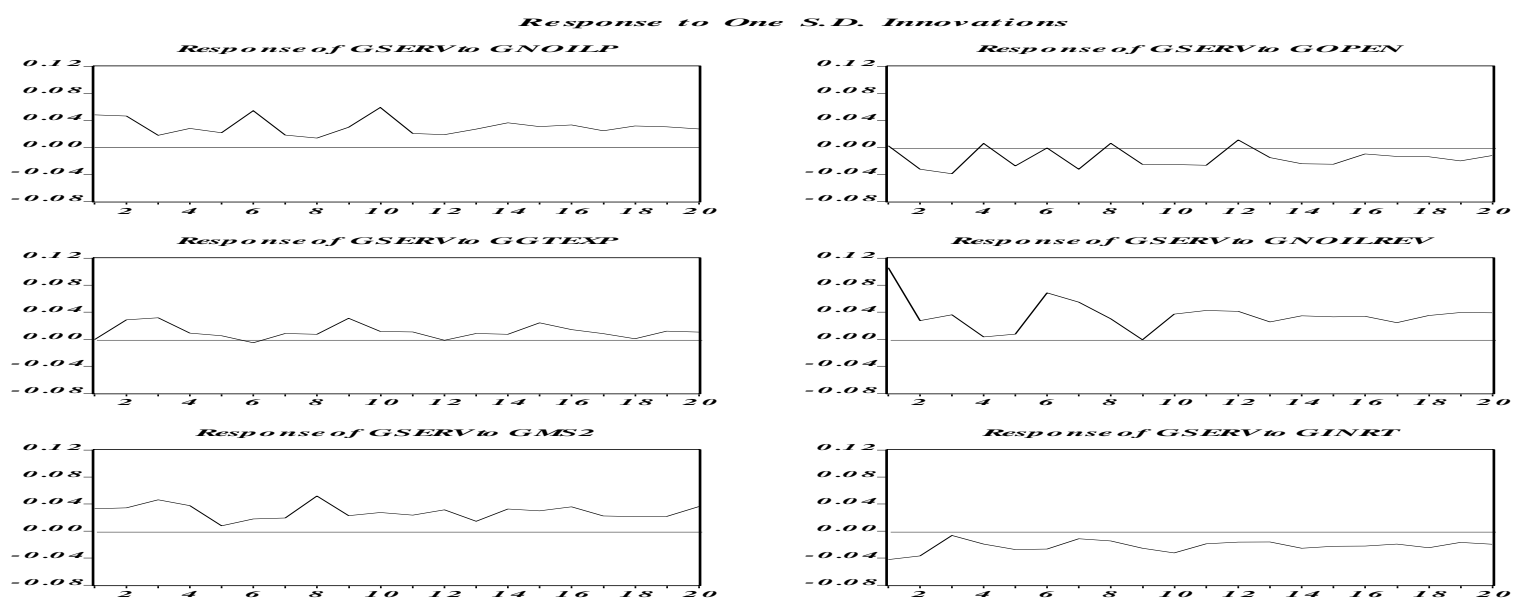

\section{Real agricultural Output}
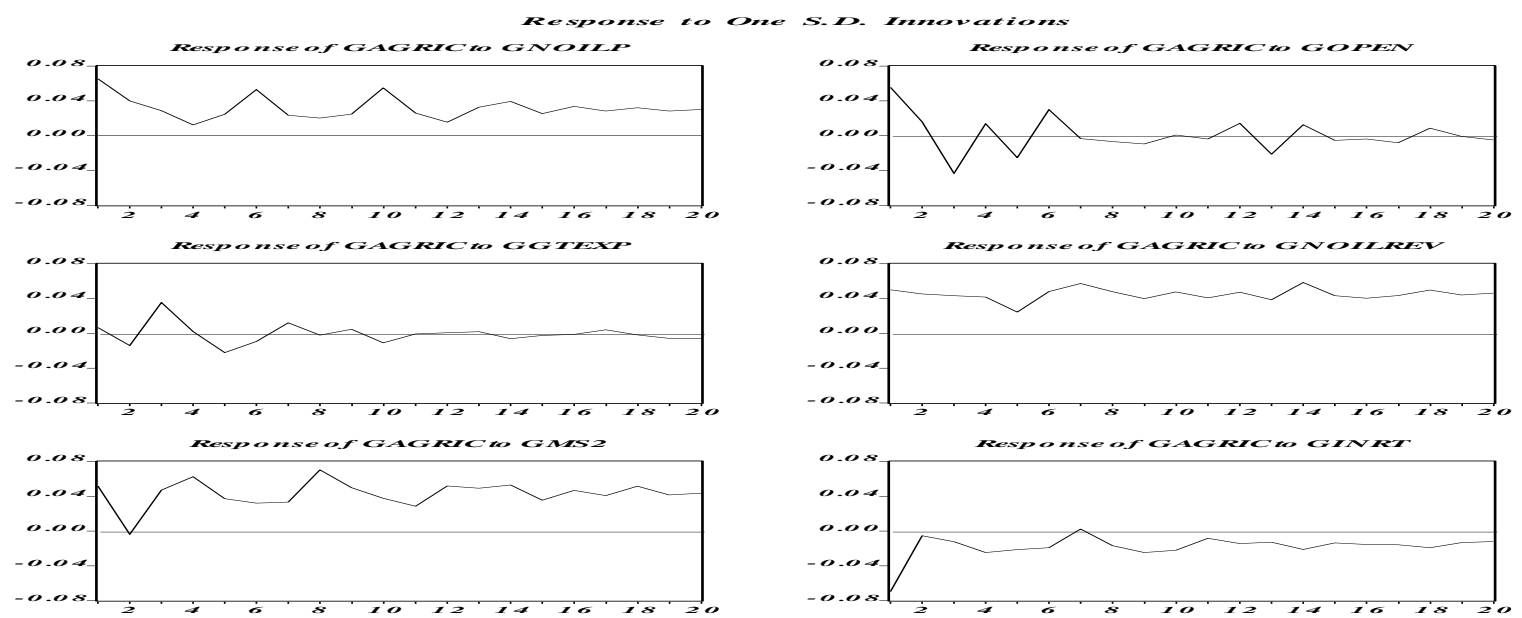
Specifically and most especially, in the first three years, the net negative effects of fiscal policy over monetary policy; $-3 \%,-1 \%$ and $-1 \%$ were suggestive of futility of using fiscal policy as growth stimulant even with an offsetting monetary policy action. In the case of contraction policy, the effects of fiscal contraction, which promoted real output, overwhelmed the contracting effects of monetary policy tightening. On the average, in the first three years also after the shock, the result showed that the real net effects of both fiscal and monetary tightening, instead of dampened, boosted aggregate demand by as much as $4 \%, 1 \%$ and $3 \%$ respectively. This was a clear evidence of macroeconomic (aggregate demand) policy ineffectiveness as tool for stimulating aggregate output in Nigeria. However, monetary policy seemed relatively effective than fiscal policy, it was not sufficient to offset the overriding negative effects of fiscal policy impulses.

The net effects of the policy shock on sectoral output also deserved attention. In contrast to the aggregate output response, the positive effects on monetary expansion overwhelmed the negative effects of fiscal expansion while in similar manner the negative effect monetary policy tightening overwhelmed the positive effects of fiscal expansion in those cases when the fiscal policy were positives. Specifically sectoral output response to net policy expansion was positive and substantial. For instance, in the first three years after the shock, the net effects were $0.06,0.03$ and 0.01 for industrial output, manufacturing; $10 \%, 2 \%, 6 \%$ respectively. The corresponding net effects were $3 \%, 5 \%, 7 \%$ and $5 \%, 1 \%, 7 \%$ for service and agricultural outputs respectively. The net effects of policy contraction were also in favor of monetary policy when fiscal policy was positive across sectors and time horizons. Several other studies on the Nigerian economy had also previously confirmed the relative effectiveness of monetary policy over the fiscal policy such studies among them were Ajisafe and Folorunso (2001) and Asogu (1998).

\section{Sensitivity Analysis}

The robustness of the result to economic openness interaction with policy effect was also examined. The interactive openness/ policy variable was used to replace the policy variable in the baseline model and openness variable was excluded to completely isolate its possible influence on the effect of the interactive term $^{2}$. The output responses to policy innovation differed from the model earlier analyzed where the policy and openness variables entered independently. Contrary to observed patterns reported in the prior model, in nearly all the cases, both expansionary fiscal and monetary policy shocks had positive effects in almost all the lags. Both fiscal and monetary contraction remained unaffected by the interaction of policy with openness. The non-oil revenue shocks' effect remained positive while interest rate policy shocks had negative effects as before.

\section{Timing and Sizes of Real Output Responses to Policy Impulses}

One of the main issues of interest was how long did it take real output to adjust after the initial policy shocks. Table 1 summarizes the maximum size and timing of these peak effects on real output growth. As results in Table 1 show, expansionary monetary policy not only has shorter lags in most cases than fiscal policy, its sizes were substantially larger than fiscal policy effects. Similar patterns were evident in the contractionary policy as well. Except in aggregate and industrial output, the maximum output reduction occasioned by policy tightening was larger and occurred at shorted lag in monetary policy than fiscal policy. Apart from industrial output the maximum reduction in real sectoral output occurred in the first year and decline progressively afterwards. The lower part of Table 1 showed the corresponding values and time lag for the interactive policy/openness variables. The aggregate output responded to both expansionary and contractionary policy differed in terms of sizes and timing. The sizes of the expansionary policy effects were higher and the timing was shorter.

\footnotetext{
${ }^{2}$ The results of the interactive model were not presented to preserve space. It is available on request from the author
} 
Table 1: $\quad$ Time lags and Sizes of Real Output Responses to Policy Impulses

\begin{tabular}{|c|c|c|c|c|c|c|c|c|}
\hline \multirow[t]{3}{*}{$\begin{array}{l}\text { Output } \\
\text { measures }\end{array}$} & \multicolumn{4}{|c|}{$\begin{array}{l}\text { Maximum output responses to } \\
\text { Expansionary Policy }\end{array}$} & \multicolumn{4}{|c|}{$\begin{array}{l}\text { Minimum output responses to contractionary } \\
\text { policy }\end{array}$} \\
\hline & \multicolumn{2}{|c|}{ Fiscal } & \multicolumn{2}{|c|}{ Monetary } & \multicolumn{2}{|c|}{ Fiscal } & \multicolumn{2}{|r|}{ Monetary } \\
\hline & $\begin{array}{l}\text { Size } \\
(\%)\end{array}$ & $\begin{array}{l}\text { Time } \\
\text { Lag }\end{array}$ & $\begin{array}{l}\text { Size } \\
(\%)\end{array}$ & $\begin{array}{l}\text { Time } \\
\text { Lag }\end{array}$ & $\begin{array}{l}\text { Size } \\
(\%)\end{array}$ & $\begin{array}{l}\text { Time } \\
\text { Lag }\end{array}$ & $\begin{array}{l}\text { Size } \\
(\%)\end{array}$ & $\begin{array}{l}\text { Time } \\
\text { Lag }\end{array}$ \\
\hline Qgdp & -2.4 & 7 & 3.6 & 8 & 1.6 & 9 & -3 & 10 \\
\hline$Q^{\text {ind }}$ & 1.5 & 3 & 9.1 & 2 & -5.7 & 1 & -3 & 8 \\
\hline $\mathrm{Q}^{\mathrm{man}}$ & 2.1 & 7 & 10.1 & 4 & 2.3 & 5 & -2.0 & 1 \\
\hline$Q^{\text {serv }}$ & 3.0 & 3 & 5.2 & 3 & -0.1 & 9 & -4.2 & 1 \\
\hline \multirow[t]{2}{*}{$Q^{\text {agric }}$} & 3.5 & 3 & 1.0 & 8 & 2.4 & 5 & -7.0 & 1 \\
\hline & \multicolumn{8}{|c|}{ Model with interactive Openness/Policy terms } \\
\hline Qgdp & 5.6 & 4 & 3.2 & 1 & 2.1 & 3 & -5.7 & 1 \\
\hline$Q^{\text {ind }}$ & 7.7 & 4 & 12.0 & 1 & -2.8 & 3 & -4.3 & 5 \\
\hline $\mathrm{Q}^{\mathrm{man}}$ & 0.1 & 3 & -5.5 & 3 & -3.7 & 5 & -8.4 & 1 \\
\hline$Q^{\text {serv }}$ & 3.4 & 3 & 4.3 & 1 & -0.4 & 5 & -8.6 & 1 \\
\hline Qagric & 0.6 & 3 & 3.5 & 1 & -2.7 & 3 & -8.6 & 1 \\
\hline
\end{tabular}

\section{Variance Decomposition of Real Outputs Growth rates}

The variance decomposition of shock response of the output growth elicited the relative contribution of each variables in the system to the variation in real output growth. Thus, indicating the strength and weakness of the policy variables in stimulating real output: an indirect test of policy ineffectiveness proposition. This information was obtained by computing variance decomposition (VDCs) of real output (Q) explained by monetary, fiscal openness and real oil price variables. The VDCs at time horizons of 10 years were shown in order to convey sense of the dynamics of the system. Only the effects on real outputs were shown in order to focus upon the variables of central interest to this study and to conserve space. Each partition in table 2 represented estimates for each measure of real output used in the model.

Table 2 shows that 'own shocks' explained substantial proportion in aggregate, manufacturing and agricultural output fluctuations. In contrast, 'oil price shocks constituted the predominant sources of variation in industrial output while non oil revenue (FP2) dominated the fluctuation in service output. The role of other macroeconomic variables differed across output measures. For instance, variation in aggregate output was explained largely by past innovation in oil price (OILP), government expenditure (FP1), and partly by non-oil revenue (FP2) changes. Specifically, the proportion explained by oil price changes declined progressively from $35 \%$ in the first year after the shock to $23 \%$ in the $9^{\text {th }}$ year while variation due to expenditure ranged from $21 \%$ in the $2^{\text {nd }}$ year after the shock to $16 \%$ in the $10^{\text {th }}$ year. Monetary policy and openness were found to be less relevant in explaining variations in real output. The proportion of variation in output explained by the monetary policy was in most cases less than $10 \%$ whereas fiscal policy explained above $20 \%$. Openness shock could not account for more that $5 \%$ of variations in real aggregate output across the time horizons.

In terms of proportion of sectoral output variation explained by the variables, oil price and money supply ranked first and second in explaining variation in most of the sectoral output fluctuations. Variation in industrial sector production could be attributed to innovation to money supply (MP1) shocks, openness and oil price changes. Less proportion (1\%) of changes in industrial production related to changes in interest rate, $5 \%$ by non-oil revenue and $10 \%$ by government expenditure shocks. This was in sharp contrast to aggregate output where none of the two monetary policy innovations accounted for any significant changes in the aggregate output fluctuation. Fiscal policy seemed less effective while monetary policy was more relevant in determining fluctuation in industrial sector growth. The manufacturing sector variation was not significantly different from the results in the industrial sector, except the deterioration in openness performance. The openness contribution to manufacturing output growth fell further, it explained less than $3 \%$ and indeed contributed insignificantly $(0.02 \%)$ to variation in manufacturing output in the first year. Oil price remained significant determinant of real manufacturing output fluctuations, it accounted for more than $30 \%$ of the variation through the periods. Money supply shocks were remarkably important in the manufacturing output 
fluctuation while fiscal policy contribution was negligible especially, government expenditure shocks. Interest rate was also found to be less relevant in determining the manufacturing output fluctuation. In most periods, it explained less than $2 \%$ as against $25 \%$ attributed to money supply and $12 \%$ that was explained by non-oil revenue.

The performance of service sector was also note worthy. In contrast to industrial and manufacturing sector performance, non-oil revenue shocks were found to be the main determinant of variation of service output growth. Government expenditure contribution was less than $6 \%$ in the entire horizon and was relatively nil $(0.00)$ in the first year. Both money supply and interest rate accounted for little variation in service output, hardly was there a period the percent contributed was more that $10 \%$ for interest rate and $16 \%$ for money supply. The variation in agricultural output seemed evenly distributed among the variables, apart from own shock which explained the largest proportion (33\% in the first year) and the expenditure (FP1), which explained the least $0.2 \%$, oil, price, openness and the two monetary policy shocks explained relatively equal proportion of about $20 \%$. However, money supply ranks first among the paired, with about $24 \%$ in the later periods. In summary, an oil price shock was found to be the main determinant on all the output growth, openness was only significant contributor in industrial output. The contribution of the two macroeconomic policy shocks was also different. Money supply ranked second to oil price, as the main macroeconomic determinant of fluctuation in real output. In contrast, government expenditure contributed significantly only to aggregate output. Interest rate performance was not impressive while non-oil revenue was a major determinant of both aggregate and sectoral output fluctuations. Therefore apart from oil price money supply and non-oil revenue were the main macroeconomic determinants of fluctuation in real output growth in Nigeria.

Sensitivity analysis of the robustness of the estimates to openness interactive effect on the real output response to policy shocks was also conducted on VDC estimations ${ }^{3}$. Incorporating the interactive terms into the model significantly altered the relationships among the variables most especially the contributions of the macroeconomic policy shocks. In contrast to the preceding results, government non oil revenue shocks that could not explain more than $19 \%$ and openness which also explained less than 5\%, now jointly explained more than $40 \%$ in the first two years and about $30 \%$ in the subsequent years of aggregate output fluctuation. Similar pattern was observed in the interest rate/openness variable. However, its performance in the service sector deteriorated as less proportion of changes in real output was accounted by changes in interest rate. Moreover, Interest, which also had less than 5\% explanatory power, now accounted for about $20 \%$ when combined with openness in the aggregate output equation. An interesting finding from these results was the confirmation of the significant role that openness plays in the effectiveness of both monetary and fiscal policy. For instance, all the IRFs estimates for both monetary and fiscal policies changed when interacted with openness. This implied that openness was a key factor in the determining the efficacy of macroeconomic policy in Nigeria. Consistently, the results appeared to be consistent with the aggregate demand channel: a rise in money supply due to increased fiscal and monetary expansion would result in exchange rate depreciation and price increase. This increase in price would cause increased cost of production and hence subsequently fall in the output level. Furthermore, the observed adverse effects of openness on monetary and fiscal policy effectiveness were consistent also with the findings of Romer (1993), Lane (1997) Terra (1998) and Karras $(199 a, b)$.

However, the overwhelming negative effects of openness shock did not appear in general to support the new growth theories that increasing openness would help the domestic economy to grow. The results also appeared to be at odds with the empirical findings of Ekpo (1995) and Oladipo (1998), and Olomola (2001) for the Nigerian economy. However, the result conformed to short run negative effects found by Saibu (2004), Aitken and Harrison (1999) in line with the theoretical argument of Levine and Renelt (1992). The theoretical argument is that that trade liberalization of a developing country whose economic fundamentals are not very strong may discourage domestic investment due to increased international competition, and its decrease would be greater than capital inflows from abroad. In this case, net investment fell as did aggregate demand. Therefore, increasing openness had negative effects on the growth rates of output.

\footnotetext{
${ }^{3}$ Variance decomposition table for the interactive model was not included due to space, they are available on request fro the author
} 
Table 2: The Variance Decomposition of Real Output Innovation

\begin{tabular}{|c|c|c|c|c|c|c|c|c|}
\hline \multirow{10}{*}{ 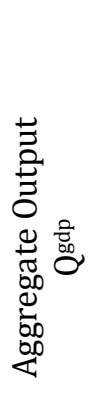 } & Period & $\mathrm{Q}$ & OILP & OPEN & FP1 & FP2 & MP1 & MP2 \\
\hline & 1 & 21.85490 & 35.51834 & 4.061640 & 18.52952 & 12.64293 & 5.830393 & 1.562274 \\
\hline & 2 & 20.20749 & 29.68484 & 3.900270 & 21.51848 & 12.78456 & 8.439508 & 3.464850 \\
\hline & 3 & 18.21986 & 28.85910 & 4.319046 & 18.86590 & 16.87967 & 9.012740 & 3.843680 \\
\hline & 4 & 19.33521 & 25.67473 & 5.826167 & 18.24253 & 16.26503 & 9.380128 & 5.276202 \\
\hline & 5 & 20.55436 & 24.24532 & 5.425362 & 18.73718 & 15.42414 & 8.972502 & 6.641134 \\
\hline & 6 & 21.31355 & 26.38653 & 5.100480 & 17.37636 & 15.23250 & 7.938173 & 6.652410 \\
\hline & 7 & 20.19458 & 24.69306 & 4.741118 & 16.75518 & 19.35981 & 8.210506 & 6.045738 \\
\hline & 8 & 18.73977 & 23.57934 & 5.070481 & 17.34714 & 19.14857 & 9.423308 & 691389 \\
\hline & 9 & 20.55626 & 23.27617 & 4.731582 & & 18.08336 & & 7.187737 \\
\hline & 10 & 20.78925 & 25.07354 & 4.465312 & 513 & 17.35657 & 8.575637 & 7.283563 \\
\hline & 1 & 8.015017 & 35.81105 & 17.12645 & 6.288381 & 6.738611 & 5.55487 & 0.465633 \\
\hline & 2 & 7.380605 & 27.61455 & 16.05165 & 0.53487 & 236231 & 32.75 & .428067 \\
\hline$\Xi$ & 3 & 7.483386 & 25.27086 & 21.21441 & 9.644271 & .024550 & 29.94 & 413974 \\
\hline & 4 & 7.944539 & 20.35262 & 26.93308 & 10.15808 & 4.898308 & 29.16389 & 0.549478 \\
\hline & 5 & 9.061657 & 18.96776 & 27.82304 & 10.67922 & 5.233550 & 27.27740 & 0.957377 \\
\hline & 6 & 9.663916 & 17.46388 & 30.32492 & 9.481239 & 5.175773 & 27.05078 & 0.839490 \\
\hline & 7 & 9.576585 & 17.50173 & 29.71515 & 9.686734 & 6.195408 & 26.43653 & 0.887865 \\
\hline & 8 & 9.452579 & 16.14140 & 32.11529 & 9.219210 & 5.794758 & 25.79953 & 1.477224 \\
\hline & 9 & 10.03360 & 14.84648 & 34.33393 & 8.943892 & 5.744885 & 24.74834 & 1.348883 \\
\hline & 10 & 10.51335 & 16.51247 & 32.76516 & 9.251262 & 5.503385 & 24.18326 & 1.271118 \\
\hline & 1 & 33.49169 & 31.4 & 0.227983 & 0.505816 & 0.40020 & 21.76592 & 2.173557 \\
\hline 3 & 2 & 27.24280 & 37.2 & 1.728563 & 1.036528 & 55 & 17.79 & 315588 \\
\hline 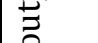 & 3 & 26.83457 & 36 & 1 & 28 & 49 & 88 & 09103 \\
\hline & 4 & 27.38497 & 28. & 25 & 2.258 & 00 & 01 & 1.902799 \\
\hline & 5 & 26.76493 & 29.2 & 3.308565 & 2.381 & 55 & 25.08 & 1.833889 \\
\hline & 6 & 24.75756 & 32.3 & 2.817978 & 2.10 & 12.6 & 23.8 & 1.536060 \\
\hline & 7 & 23.98424 & 33.6 & 2.821092 & 2.271545 & 12.54222 & 23.26708 & 1.457641 \\
\hline & 8 & 25.82994 & 30.88939 & 2.555671 & 2.063520 & 12.33985 & 25.00036 & 1.321275 \\
\hline & 9 & 26.26696 & 30.05537 & 2.864996 & 1.919713 & 12.44393 & 25.11343 & 1.335604 \\
\hline & 10 & 25.13141 & 31.41485 & 2.821144 & 1.830405 & 12.34070 & 25.24151 & 1.219978 \\
\hline & 1 & 12.83196 & 12.35811 & 0.032523 & 0.002028 & 59.58185 & 5.759716 & 9.433816 \\
\hline & 2 & 9.730947 & 17.062 & 3.988303 & 3.147734 & 45.53106 & 8.641 & 1.89786 \\
\hline 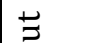 & 3 & 8.037656 & 14.69064 & 7.855417 & 5.630457 & 40.59407 & 13.50067 & .691091 \\
\hline & 4 & 7.477603 & 15.78648 & 7.342023 & 5.424239 & 37.49080 & 16.47 & 0.00171 \\
\hline & 5 & .809305 & 15.8 & 8.77 & 5.091 & 72 & & 4130 \\
\hline & 6 & 8.958532 & 18. & & & & 12.97 & 10.46575 \\
\hline & 7 & 871 & 17. & & & & 12.43 & 9.702863 \\
\hline & 8 & 7.797125 & & & & & & 9.379692 \\
\hline & 9 & 7.505272 & & & & & & 9.857144 \\
\hline & 10 & 7.630631 & 20. & 8.2 & 58 & 33 & 53 & 10.20554 \\
\hline & 1 & 33.01346 & 16.4 & 11.8 & 00 & 9.626 & 10.24786 & 18.68707 \\
\hline & 2 & 28.85875 & 19.3 & 10.99427 & 0.788904 & 15.00565 & 8.852501 & 16.14486 \\
\hline & 3 & 22.90037 & 17.31302 & 13.53729 & 3.865392 & 16.64850 & 12.66418 & 13.07125 \\
\hline & 4 & 21.04354 & 14.84295 & 11.76442 & 3.249687 & 17.72242 & 19.08584 & 12.29114 \\
\hline & 5 & 20.25293 & 14.64041 & 11.92221 & 3.905291 & 17.23168 & 20.00947 & 12.03802 \\
\hline & 6 & 19.28197 & 17.22897 & 11.67842 & 3.485075 & 18.59424 & 18.82694 & 10.90439 \\
\hline & 7 & 17.92317 & 16.68075 & 10.75643 & 3.434684 & 22.15479 & 19.01684 & 10.03333 \\
\hline & 8 & 16.02860 & 15.40328 & 9.629943 & 3.060825 & 22.86010 & 23.70356 & 9.313696 \\
\hline & 9 & 15.86828 & 14.94823 & 8.978582 & 2.844341 & 23.05963 & 24.95031 & 9.350626 \\
\hline & 10 & 5.03793 & 17.07517 & 8.170333 & 2.727829 & 23.59312 & 24.32288 & 9.072740 \\
\hline
\end{tabular}




\section{Policy Implication and Conclusion}

In summary, an oil price shock was found to be the main determinant on all the output growth, openness was only significant contributor in industrial output. The contribution of the two macroeconomic policy shocks was also different. Money supply ranked second to oil price, as the main macroeconomic determinant of fluctuation in real output. In contrast, government expenditure contributed significantly only to aggregate output. Interest rate performance was not impressive while non-oil revenue was a major determinant of both aggregate and sectoral output fluctuations. Therefore apart from oil price, money supply and non-oil revenue were the main macroeconomic determinants of fluctuation in real output growth in Nigeria. However, the fact that against expectation, the expansionary policy shocks adversely affected real output while contractionary policy shocks boosted aggregate demand confirmed the irrelevance of macroeconomic policy as the veritable tool for stimulating real growth in Nigeria. Moreover, in terms of timing of the policy impacts, monetary policy shocks not only had shorter lags than fiscal policy shocks, its sizes were substantially larger. Monetary policy shocks had short run effects on output than the fiscal policy shocks, implying that fiscal policy had longer response lag than monetary policy in Nigeria.

\section{Conclusion}

The general conclusion from these findings was that, expansionary policy through increased government spending did not have the same effects as increasing money supply, while money supply increases aggregate spending, increased government spending crowd out private spending, hence less effective in boosting aggregate demand in Nigeria. Similarly, tight monetary policy through increase interest rate did not have the same effect as increasing the tax rate and other personal income reduction strategies, hence could not be use also as a means of curtailing aggregate spending. The negative consequences of monetary and fiscal policies in significantly affecting real output growth in Nigeria means that the behavior of real output was varied under alternative fiscal and monetary policy mix. The major growth determinant factors observed in this study were international oil price changes and trade openness. Thus, fluctuations in real output in Nigeria were externally induced. The degree of openness, which was found to have adverse effect on policy ineffectiveness and the asymmetry in policy effects made relying on macroeconomic policy to be less attractive.

\section{References}

Aitken, B. and Harrison, A. (1999). Do Domestic Firms Benefit from Direct Foreign Investment? Evidence from Venezuela. American Economic Review, 89: 605-618.

Ajisafe, R. O. and Folorunso, B. A. (2001). The Relative Effectiveness of fiscal and monetary policy in macroeconomic management in Nigeria. The Nigerian Economic and Financial Review, 6(1): 147-161.

Apergis, N. and Miller, S. (1998). Macroeconomic Rationality and Lucas's misconception Model: Further Evidence from Forty-one Countries. A Paper presented at the $45^{\text {th }}$ Atlantic conference, Rome Italy.

Asogu, J. O. (1998). An economic Analysis of the Relative Potency of Monetary and fiscal policy in Nigeria. CBN Economic and Financial Review, 36(2): 30-65.

Bernanke, B. S. and Blinder, A. S. (1992b). The Federal Funds rate and the channel of Monetary policy transmission. American Economic Review, 82: 901-921.

Blanchard, O. J. and Gali, J. (2007). Real Wage Rigidities and the New Keynesian Model. Journal of Money, Credit, and Banking, 39(1): 35-66.

Bryant, R., Henderson, D., Holtham, G. P. and Symansky, S. (1988). Empirical Macro Economics for Independent Economies, Brookings Institution, Washington, DC.

Burement H. and Dogan, B. (2001). Openness and the Efficiencies of Monetary Policy Evidence from Turkey. Applied Economic letter, 4: 217-221.

Dale, S. and Haldane, G. (1995). Interest rates and the channels of monetary transmission: Some sectoral estimates. European Economic Review, 39: 1611-1626.

Dennis, R. (2001). Monetary policy and Exchange rates in small open Economies. FRBSF Economic Letter Issue, 161-164. 
Ekpo, A. H. (1995). Openness and Economic growth in Nigeria: Proceedings of the Annual Conference of Nigeria Economic Society.

Friedman, B. and Kuttner, K. (1992). Money, income, prices, and interest rates. American Economic Review, 82: 472-492.

Ganley, J. and Salmon, C. (1996). The industrial impact of monetary policy, Bank of. England Quarterly Bulletin, 3: 288-98.

Gauger, J. and Enders, W. (1989). Money neutrality at aggregate and sectoral level. Southern Economic Journal, 55(3): 676-680.

Gertler, M. and Gilchrist, S. (1994). Monetary policy, business cycles and the behaviour of Small manufacturing firms. Quarterly Journal of Economics, 109: 309-40.

Guncavdi, O. and Kucukcifci, S. (2001). Foreign trade and factor intensity in an open developing country: an input-output analysis for Turkey. Russian and East European Finance and Trade, 37(1): 75-88.

Karras, G. (1999a). Openness and the effect of monetary policy. Journal of International Money and Finance, 18: 13-26.

Karras, G. (1999b). Monetary Policy and the exchange rate: The role of Openness. International Economic Journal, 13(2): 75-88.

Lane, P. R. (2000). Asymmetric shocks and Monetary Policy in a Currency Union. Scandinavian Journal of Economics, 102: 585- 604.

Levine, R. and Renelt, D. (1992). A sensitivity Analysis of cross country growth regressions. American Economic Review, 82(4): 942-963.

Odusola, A. F. and Akinlo, A. E. (2003). Assessing the impact of Nigeria's naira depreciation on output and inflation, Applied Economics, 35: 691-703.

Ogun, T. P. and Akinlo, A. E. (2010). The effectiveness of Bank Credit Channels on Monetary Policy Transmission: The Nigerian Experience. African Economic and Business Review, 8(2): 16-29.

Oladipo, O. S. (1998). Trade liberalization and economic Growth in Nigeria. Ife Social Sciences Review, 15(1): 80.

Olaloye, A. O. and Ikhide, S. I. (1995). Economic Sustainability and the Role of Fiscal and Monetary Policies in a Depressed Economy: The Case Study of Nigeria. Sustainable Development, 3: 89-100.

Olomola, P. A. (2001). Determinant of Long Run Growth in Nigeria. A PhD thesis dissertation in the Department of Economics Obafemi Awolowo University Ile-Ife.

Olomola, P. A. and Adejumo, A. V. (2006). Oil Price shocks and Macroeconomic Activities in Nigeria. International Research Journal of Finance and Economics, 3: 28-34.

Romer, D. (1993). Openness and Inflation Theory and Evidence. Quarterly Journal of Economics, 11(4): 869903.

Saibu, M. O. (2004). Openness and Economic growth in Nigeria: Further Evidence on Causality Issue. South African Journal of Economics and Management Sciences, 7(2): 115-131.

Sim, C. A. (1980). Macroeconomics and reality. Econometrica 48: 1-48.

Stock, J. H. and Watson, M. W. (1989). New indexes of coincident and leading economic indicators, NBER Macroeconomic Annual, 351-393.

Terra, C. T. (1998). Openness and inflation" A New Assessment. Quarterly Journal of Economics 39: 312-320. 